Dossier: Theological Challenges of Religious Pluralism - Editorial (c) (1)

\title{
A New Way of Being Christian
}

Uma nova maneira de ser cristão

Paul F. Knitter*

I take my cues from the title and contents of a book by Tom Fox, Pentecost in Asia: A New Way of Being Church (2002). Fox describes how the many facets of this "new way" boil down to one word: dialogue. The Asian Catholic Bishops, listening to their people and assisted by their theologians, have clearly and powerfully insisted that the Christian Church can be a church-in-Asia only if it is in authentic dialogue with other Asian religions and with the many Asian poor and marginalized.

In my own life as a Christian believer and in my labors as a Catholic theologian, I have come to realize that what is true of the local churches in Asia is just as true of the universal church. Pentecost, which might be called "the big bang" that launched the ecclesia, will continue rippling through the ecclesial universe of the third millennium mainly through the energy of dialogue. A growing number of Christians, mainly within the so-called mainline churches, are coming to realize that to be a truly Christian church, they have to be a dialogical church. Let me try to explain, briefly, what I mean.

Editorial received on November 18, 2015 and approved on December 05, 2015.

* Professor Emeritus of Theology, World Religions, and Culture Union Theological Seminary, New York City. Country of origin: USA. Email: pknitter@uts.columbia.edu

Horizonte, Belo Horizonte, v. 13, n. 40, p. 1729-1735, Oct./Dec. 2015 - ISSN 2175-5841 


\section{Reasons for the Shift to Dialogue}

The world which the Christian churches are called to serve, challenge, and transform is a world in dire need of dialogue. This need is rooted in two evident qualities of our present global reality: ours is a pluralistic world and it is a violent world.

Pluralism-the vast variety of peoples, cultures, religions-has, of course, always colored the fabric of human history. But today, mainly because of the pushbutton speed of communication and travel, those differing colors have become all the more evident. In fact, for many people, they have become bewildering or blinding. This is especially true of the multiple colors of religions. Religious pluralism-the abundant, persistent, exuberant diversity of religions-is confronting and perplexing Christians as never before. The shapes, colors, and even smells of other religions are no longer on the other side of the world. They often emerge from the house next door!

The many-ness of religions isn't going to go away. It seems that religious pluralism is "as it was it in the beginning, is now, and ever shall be." If that is the case, the simple, immediate conclusion is that Christians have to learn to co-exist, to live with and be good neighbors to people who are Buddhists, Hindus, and Muslims, etc. But being good neighbors to each other means more than tolerance, more than just accepting the pluralistic state of affairs. Rather, it means learning about each other, appreciating and valuing each other. Pluralistic co-existencethat is, really living and thriving together as different religions-requires dialogue.

But co-existence is not enough. We have to do more together because our world is not just a pluralistic world; it is also a violent world. I am talking mainly (but not only) about the violence that erupts from the barrel of a gun, the impact of a missile, the explosion of an airplane crashing into a building. I am talking about military or terroristic violence. The dreams of a new age of peace after the fall of the 
Soviet Union have turned, it seems, into nightmares. Besides the multiple, rampaging conflicts of ethnic and/or religious groups, the world is witnessing the "clash of civilizations"-a clash fueled by the terrorism of scattered movements pitted against the military might of a world power. All too often, religion is used to fuel such violence.

But if such "use" of religion for violence is a "misuse," then the religions of the world are going to have to do something to prevent that misuse. And they are going to have to do it together. So, besides co-existence, we also need cooperation among the religious traditions of the world. Speaking as a Catholic Christian, I feel the need to cooperate with persons of other religions in order to prove that religions are a much more powerful tool for peace than they are a weapon of war. But such cooperation can be realized only through dialogue. The well-known dictum of Han Küng rings true: "There will be no peace among nations without peace among the religions. And there will be no peace among the religions without dialogue among the religions." (KÜNG, 1991, p. 15).

\section{The Newly Felt Demands of Dialogue}

But what do we mean by dialogue? That is an important question, since dialogue is a term that gets thrown around facilely and sloppily. As it is generally understood in interreligious encounters, dialogue can be described as follows: a relationship among differing parties in which all parties both speak their minds and open their minds to each other, in the hope that through this engagement all parties will grow in truth and well-being. Dialogue, therefore, is always a two-way street that can lead all who travel it to greater understanding and cooperation. All participants in a dialogical encounter have to be ready both to listen and to speak, to teach and be taught. A true dialogue is always a "give and take"-one gives witness to what one holds to be true and at the same time accepts the witness of what the other holds true and dear. Everyone seeks to convince and is ready to beconvinced. And if in the dialogue I come to see and feel the truth of your 
position, then I must also be ready to clarify, correct, even change my views. Dialogue is always exciting; it can also be threatening.

And it is just this kind of dialogue that one of the most cautious and conservative of the mainline Christian churches has been trying to foster over recent decades. This, I believe, constitutes a milestone in Christian awareness. I'm talking about my own Christian community, the Roman Catholic Church. Since the Second Vatican Council in the 1960s, the Catholic Church has held up interreligious dialogue as an ideal-one might even say, an obligation-for all Christians.

In 1965, the bishops at Vatican II called on all Catholics to "engage prudently and lovingly in dialogue and cooperation" with other religious traditions (Nostra Aetate - NA, par. 2). In 1984, this gentle invitation became a requirement when the Vatican Secretariat for Non-Christian Religions (later called the Pontifical Council for Interreligious Dialogue) announced that dialogue is an essential part of the Church's mission (SECRETARIAT FOR NON-CHRISTIANS, 1984). Then in 1991, the meaning of dialogue was boldly clarified in Pope John Paul II's Encyclical Redemptoris Missio (RM - December 7, 1990), and in the Declaration Dialogue and Proclamation (DP) from the Pontifical Council for Dialogue (1991). These official statements expressly acknowledged that the intended fruits of dialogue are in the "mutual enrichment" of all sides ( $\mathrm{RM}$ \# 55, DP \# 9), that in the dialogue Christians should allow themselves to be "questioned," perhaps "purified," (DP \# 32), maybe even "transformed." (DP \#47) Surprisingly, the Vatican document even goes so far as to recognize that in a true dialogue, all the participants (including Christians) must be open to being "converted," that is, open "to leave one's previous spiritual or religious situation in order to direct oneself to another." (DP \# 41) Clearly, Christians have finally begun to recognize dialogue as a two-way street. 


\section{Catholic $=$ Dialogical}

So as Christians step into the new millennium, many of them (certainly not all!) in the mainline churches are doing so with a new and quite different understanding of how Christians are to relate to other religions and other philosophies. They are coming to a deeper, more adequate understanding of what the word "catholic" means. (With a small "c" and without "Roman" in front of it, "catholic" was used in the early creeds to describe all the Christian communities). Literally, "catholic" signifies "universal"-related to and sent into the whole world with its many peoples and cultures and religions. But for most of their history, the churches have understood this universal relatedness as a one-way street. Christians bring the truth and salvation to others; they give, the other religions receive. Such was the understanding of "Christian mission."

But "catholic" understood as "dialogue," and "dialogue" understood as Pope John Paul II and the Pontifical Council for Dialogue do, mean that the relationship between Christianity and other cultures and religions must be two-way. If the Christian churches are to grow and be faithful to the Gospel of Jesus, they must not only deliver the Good News but also be open to whatever Good News God may be providing through other religious traditions. Christian mission now requires not only "teaching all nations" but also learning from all nations. Only then can Christians cooperate with other religions in the work of overcoming violence and bringing justice to the poor of our planet, and to our poor planet suffering from environmental devastation. To call themselves "catholic Christians" means that the community of Jesus followers must be in a genuine, dialogical relationship with others-with people and religions who are really different. Dialogue is becoming a meaningful, challenging "new way of being Church." 


\section{Remaining Challenges}

But this is only half the picture of what is new in my field of interreligious theology. This new understanding of what it means to be church contains some profound, unsettling challenges for Christian theology and self-understanding, challenges which, I'm sad to say, are not being sufficiently taken up or even recognized. Briefly stated: there are definite tensions, if not downright contradictions, between the new ecclesiology that extols dialogue as the new way of being church and the traditional Christology that extols Jesus as the one and only savior and as the bearer of God's full, definitive, and unsurpassable revelation. Unless these tensions or contradictions are squarely faced and resolved, I fear that Christians' dialogue with other religions will not be honest and successful and may well turn out to be exploitative.

How can Christians carry out a dialogue with other believers that is genuinely a two-way relationship-as Pope John Paul II said, a conversation in which Christians are truly open to learning as much as they want to teach, in which they are ready to be "questioned [...] purified [...] transformed, even converted"-if they believe that God has given them the one source of salvation and the full, final, normative truth over all other truth? They hold, as it were, the divinely-given trump card for all other religious truth. It would seem, therefore, that within the mainline Christian churches today, there is a tension between the practice of dialogue to which Christians are being called on the one hand, and the theory of traditional Christology. This, I believe, is one of the most serious and pressing challenges facing the Christian churches today.

It is a challenge that calls Christian theologians to the task that has so often driven theology throughout the centuries of church history-how to resolve the tensions that naturally arise as the church moves through different times and different cultures between the practice of Christian living and the theory of Christian believing. The particular challenge I am pointing to in these reflections 
calls theologians to work out a Christology, an understanding of Jesus the Christ, that will preserve his distinctive message without subordinating the distinctive identities and message of other religious figures. It will be a Christology that enables and requires of Christians an ongoing, full commitment to the Gospel of Jesus and at the same time a genuine openness to the truth that may be challenging them in other religious traditions.

Some such challenge-how to be committed to one's own identity and at the same time truly open to that of others-faces all religious communities. My hopes are that in the coming decades we Christian theologians can offer some good example of how that challenge can be met.

\section{REFERENCES}

FOX, Tom. Pentecost in Asia: A New Way of Being Church. New York: Orbis Books, 2002.

KÜNG, Hans. Global Responsibility: In: Search of a New World Ethic. New York: Crossroad, 1991. p. 15.

JOHN PAUL II'S. Encyclical Redemptoris Missio. December 07, 1990. Available at: <http://w2.vatican.va/content/john-paul-ii/en/encyclicals/documents/hf_jpii_enc_07121990_redemptoris-missio.html>. Accessed: Oct. 12, 2015.

PONTIFICAL COUNCIL FOR INTER-RELIGIOUS DIALOGUE. Dialogue and Proclamation. Reflection and orientations on interreligious dialogue and the proclamation of the gospel of Jesus Christ (1). May 19, 1991. Available at: < <http://www.vatican.va/roman_curia/pontifical_councils/interelg/documents/rc_pc_int erelg_doc_19051991_dialogue-and-proclamatio_en.html>.Accessed: Oct. 12, 2015.

\section{SECRETARIAT FOR NON-CHRISTIANS. The Attitude of the Church toward}

Followers of Other Religions. Secretariate for Non-Christian Religions, Vatican City, 1984. Available at Vatican website. 